\title{
STUDENTS' SATISFACTION WITH THEIR HOST CITY: CASE OF JELGAVA, LATVIA
}

\author{
Liga Feldmane \\ University of Latvia, Latvia \\ ljankava@gmail.com
}

\begin{abstract}
Satisfaction or dissatisfaction with the university city can influence the student's decision to continue to build his/her life in the city, to return to the previous place of residence or move to live elsewhere. Thus, it also influences the future development of the university city, as educated inhabitants are an important resource for further development of the city. In order to examine students' satisfaction with life in their host city the research was carried out at the Latvia University of Life Sciences and Technologies, which is located in Jelgava, the fourth biggest city of Latvia. In questionnaire survey students were asked to evaluate their satisfaction with overall life in the city, their current accommodation and various city's social, infrastructure and environmental attributes as well as evaluate their sense of belonging to Jelgava city. The results revealed that overall satisfaction with life in Jelgava was rather average among students and lower compared with permanent inhabitants of Jelgava and the key drivers of students' overall satisfaction with life in the city were the sense of belonging, satisfaction with current housing, educational facilities, noise level and cultural facilities. The highest level of satisfaction was with such attributes as educational facilities, green spaces, cleanliness, availability of retail shops, cultural facilities, public spaces and sports facilities, while moderate satisfaction was observed with the quality of the air, safety, the state of the streets and buildings and the noise level. At the same time the lowest satisfaction was observed with public transport, job opportunities and healthcare services. Half of the respondents felt belongingness to Jelgava and this sense was influenced by the students' age, housing tenure and duration in the current residence. More than half of students expressed satisfaction with their residence and the most satisfied were the students, who lived in private houses, while the students from dormitories were the least satisfied with their housing conditions.
\end{abstract}

Keywords: students' satisfaction, residential satisfaction, Jelgava, university city.

\section{Introduction}

Study time is an important period in the individual's life and it is influenced not only by the university, but also the environment outside the university's premises. The time spent by students in the university city creates a certain picture of the city and impacts overall educational experience. Students' satisfaction is an important factor both for the university and the hosting city. Studies have shown that satisfied students have better education performance and higher grades [1]. Since nowadays students are increasingly seen as consumers of higher education services [2], satisfaction should be an important factor for universities to increase the number of future students. Satisfied students are the best advertisers of the university and more likely will attract new students through positive experience in the study process [3]. The increase in the number of students can make an important contribution also to the economy of the hosting city by consuming local services, thus creating a need for additional jobs [4]. Satisfaction or dissatisfaction with the university city can influence the student's decision to continue to build his/her life in the city, to return to the previous place of residence or move to live elsewhere. Since highly educated citizens are one of the main preconditions for innovative and economic performance of the territory [5], it is important for cities to attract graduates for staying in the city after graduation and to prevent "brain drain". Since education recently has become international service, cities compete with each other for students and not only for local, but also for foreign students [6].

Although, studies about students' satisfaction are carried out in Latvia, they are mainly oriented to identify satisfaction with the living conditions [7;8] and physical environment of university [9]. Instead, there is lack of studies about students' attitude towards their host city.

The aim of the research is to evaluate students' satisfaction with life in their host city and students' life satisfaction in Jelgava is defined as the research object. In order to achieve the aim the following tasks have been set: 1) to investigate how satisfied students are with the life and city's attributes in Jelgava; 2) to identify which are the key attributes that influence students' overall satisfaction with life in Jelgava; 3) to find out how strong is the students' sense of belonging to Jelgava. 


\section{Materials and methods}

In order to investigate students' satisfaction with life in their host city a research was conducted in Jelgava at the Latvia University of Life Sciences and Technologies, which is the fourth biggest higher education and science establishment in Latvia with more than four thousand students [10] and offers higher education programs in agriculture, engineering and social sciences. Jelgava is the fourth biggest city of the country with approximately 56 thousand inhabitants; it is conveniently situated in the middle of the country near the capital city Riga and is considered to be the students' capital of Latvia as a result of the strong interaction between the university, students and the city. Major part of the university buildings and student dormitories are situated in the central part of Jelgava, thus the presence of students is highly visible and affects the city's social, economic and cultural life.

A questionnaire survey was chosen as a research method and 269 students in total (approximately $6 \%$ of all students of the Latvia University of Life Sciences and Technologies) were questioned from different study programs, who lived in Jelgava in the survey period in November 2018. Major part $(83.3 \%)$ of respondents was in the age group between 18 and 24, while $16.7 \%$ were 25-34 years old. The survey sample consisted of $67.7 \%$ women and $32.3 \%$ men; $88.5 \%$ of all respondents were Latvians, while $11.5 \%$ were representatives of other nationalities, mainly Russians. There were more those respondents who answered that they were not working for paid work $(60.6 \%)$, while $39.4 \%$ of respondents were working alongside their studies. Since previous studies [3] showed that housing conditions could affect satisfaction with life in the residence, students were asked to answer questions about their housing type, duration of residence and previous residence. More than half of respondents $(53.9 \%)$ were living in university dormitories, $33.5 \%$ in block of flats, while $12.6 \%$ - in private houses. Comparing the survey sample by tenure status $68.6 \%$ of respondents were living in rented housing and $31.4 \%$ in housing where one of household's members owned it. Almost in equal amount (approximately $40 \%$ ) were respondents who lived in the current residence less than one year and respondents who's duration in the current residence was between one and five years, while $20 \%$ of respondents lived in the current residence more than 5 years or since the birth. Majority of respondents have arrived in Jelgava from another territory of Latvia - 14.1\% from the capital city Riga, $33.8 \%$ from other cities of Latvia, $23.4 \%$ from rural municipalities - while $28.6 \%$ of respondents lived in Jelgava also before studies.

In the survey the students were asked to evaluate their satisfaction level with overall life in Jelgava, different infrastructure, environmental and social aspects in the city as well as to evaluate their sense of belonging to Jelgava. Satisfaction level as well as the sense of belonging were asked to be expressed in 5-point Likert scale, where , 1" was the lowest satisfaction or sense of belonging level and ,5" - the highest level. Mean values (M) and standard deviations (SD) were calculated in the data analysis process in order to compare the survey data. Kolgomorov-Smirnov test was applied to determine that the data did not correspond to the normal distribution and therefore non-parametric methods - Mann-Whitney and Kruskal-Wallis tests - were applied to analyse differences between various student groups. Lastly a stepwise multiple regression analysis was applied to identify which attributes of Jelgava contributed most to students' overall satisfaction with life in the city.

\section{Results and discussion}

The survey results revealed that the overall satisfaction with life in Jelgava among students, who study at the Latvia University of Life Sciences and Technologies, was rather average, because $69.1 \%$ of all respondents answered that they were rather or very satisfied with life in Jelgava $(M=3.74$, $S D=0.843$ ). In comparison to the survey about the life quality in the cities of Latvia, which was carried out by Central Statistical Bureau of Latvia on 2017 [11], $95.2 \%$ of respondents from Jelgava expressed satisfaction with life in this city and therefore students were more critical about their life in the city.

In order to investigate what characteristics of respondents and their housing influence overall satisfaction with life in Jelgava non-parametric tests were applied to examine whether there were differences between different groups of respondents. The results indicated that the gender, nationality and housing tenure did not influence students' satisfaction with overall life in the host city, while in contrast the occupation ( $p=0.019)$, age $(p=0.001)$, type of housing $(p=0.002)$, duration of residence $(p=0.023)$ and previous residential place $(p=0.000)$ influenced it. Students who worked alongside 
their studies showed a higher level of satisfaction $(M=3.88, S D=0.813)$ compared with students who were entirely devoted to studies $(M=3.64, S D=0.851)$. Younger respondents between the age $18-$ 24 were less satisfied $(M=3.66, S D=0.832)$ compared with the students in the age group 25-34 $(M=4.11, S D=0.804)$. The students who lived in the university dormitories were the least satisfied with their life in Jelgava $(M=3.59, S D=0.795)$, while the students who lived in blocks of flats $(M=3.84, S D=0.886)$ and private houses $(M=4.06, S D=0.814)$ were significantly more satisfied. These results correspond with the previous studies in residential satisfaction field, where it was discovered that residential satisfaction has increased with the age and that financial situation and housing conditions of household were strongly connected with overall satisfaction [12].

The study also showed that students who lived in current residence from the birth were significantly more satisfied with life in Jelgava $(M=4.08, S D=0.906)$ compared with those who have in-migrated in the city recently. First year students were slightly more satisfied $(M=3.75, S D=0.766)$ compared with those who lived in the city for 1-5 years $(M=3.6, S D=0.896)$, while satisfaction with life in the city increased again for those who have lived there more than 5 years. Although no significant differences were observed between in-migrants from Riga $(M=3.63, S D=0.786)$, other cities of Latvia $(M=3.58, S D=0.895)$ and rural municipalities $(M=3.59, S D=0.733)$, those who lived in Jelgava also before studies were significantly more satisfied $(M=4.09, S D=0.798)$. Similar results have been reported in previous studies in other countries, where it was discovered that migration event caused a boost in migrants' happiness which after some time decreased [13] and that residents who lived in their residence for longer time evaluated their happiness higher than residents who have changed their residence recently [14]. Ballas and Tranmer [14] explain this phenomenon with the importance of social networking in local community in person's life what gets stronger with the time spent in the residence. Insch and Florek [15] point out that those who have lived in residence since birth have more positively skewed assessment because they have no other experience and no basis for comparison.

Results of the empirical study in New Zealand [3] revealed that the most important attributes of the hosting university city for students were accommodation as well as socializing and the sense of community. According to the previous study of students' social and economic conditions in Latvia in 2017 [10] $74 \%$ of students in total were satisfied with housing conditions from whom the most satisfied were students who shared housing with parents, while the students who lived in dormitories were significantly less satisfied. In the case of Jelgava, $64 \%$ of students expressed satisfaction with their residence, though statistically significant differences were observed considering the type of housing $(p=0.000)$. The most satisfied $(86.7 \%)$ were students who lived in private houses $(M=4.3$, $S D=1.088$ ), while only $53.2 \%$ of students from dormitories were satisfied with their housing conditions $(M=3.53, S D=0.948)$. Although students who lived in dormitories were significantly less satisfied compared with others, though their satisfaction level was higher than in Latvia on average, where only $45 \%$ of students who were living in dormitories expressed satisfaction with their housing.

In order to discover how strong is the students' sense of belonging to Jelgava in the survey the students were asked to evaluate this indicator, which included both social and physical links to the city and community. In total $50.7 \%$ of students answered that they felt rather high or very high sense of belonging to Jelgava, $34.7 \%$ expressed neutral opinion, while $14.5 \%$ did not feel belonging to the city $(M=3.53, S D=1.051)$. From the students, who expressed the sense of belonging to Jelgava, one third $(33 \%)$ answered that the main reason of belongingness was the fact that they were born in the city, $37 \%$ liked the physical environment of Jelgava, while $18 \%$ mentioned as the main reason high satisfaction with society in the city. Statistically significant differences were not observed $(p>0.05)$ between different genders and ethnical groups. In contrast, the students' age influenced the sense of belonging - students from the age group 25-34 had stronger sense of belonging (73.3\%) than students from the age group 18-24 (46.2\%). Also the students who lived in privately owned housing felt stronger belongingness $(M=4.01, S D=1.071)$ compared with those who rented it $(M=3.31$, $S D=0.972$ ). As it was expected, the sense of belonging increased with duration in the city, as only $41 \%$ of these who had lived in Jelgava for less than one year expressed the sense of belonging to it, while $72.2 \%$ of those who have lived more than 5 years felt belongingness. Correlation between the sense of belonging to Jelgava and overall satisfaction with the city was discovered - those who felt the sense of belonging to the city were also more satisfied with the life in it $(M=4.02, S D=0.745)$, while 
students who have not felt the sense of belonging were more critical $(M=3.43, S D=0.831)$. These results were similar with the research of Smith [16], who discovered that the sense of belonging contributed to higher level of residential satisfaction.

Overall satisfaction with a city is influenced by many social, physical and environmental factors, therefore students of Jelgava were asked to evaluate their satisfaction with public transport,

healthcare services, sports facilities, cultural facilities, the state of the streets and buildings, public spaces (markets, squares), green spaces, availability of retail shops, educational facilities, the quality of the air, the noise level, cleanliness, safety and job opportunities. As it is shown in Table 1, the highest level of satisfaction among students was with such indicators as educational facilities, green spaces, cleanliness, availability of retail shops, cultural facilities, public spaces and sports facilities, while moderate satisfaction was observed with the quality of the air, safety, the state of the streets and buildings and the noise level. The results revealed that the lowest students' satisfaction was with public transport, job opportunities and healthcare services. In comparison the study about satisfaction with life quality indicators in the city in 2017 of Jelgava residents [11] revealed that the highest satisfaction was observed with availability of retail shops, green spaces, cleanliness, while the lowest with the state of streets and buildings, public transport and health care services. Therefore, this survey confirms that students were more critical compared with the permanent residents of the city about environmental factors (quality of the air and the noise level), while the state of the streets and buildings did not bother them as much as the permanent residents of Jelgava. Lower satisfaction level with environmental factors could be explained by the fact that a significant number of students have arrived in Jelgava from rural municipalities or smaller towns, where the air quality is better and the noise level is lower. At the same time, such indicators as public transport and healthcare services were evaluated the most critical in both surveys approving their importance for both respondent groups and pointing out them as the weak points of Jelgava.

Table 1

Students' satisfaction with life quality attributes in Jelgava

\begin{tabular}{|c|c|c|c|c|c|}
\hline Attribute & $N$ & Min & Max & Mean & $S D$ \\
\hline Public transport & 265 & 1 & 5 & 2.93 & 0.969 \\
\hline Health care services & 266 & 1 & 5 & 3.19 & 0.822 \\
\hline Sports facilities & 269 & 1 & 5 & 3.75 & 0.798 \\
\hline Cultural facilities & 269 & 1 & 5 & 3.83 & 0.806 \\
\hline The state of the streets and buildings & 269 & 1 & 5 & $c>3.49$ & 0.875 \\
\hline Public spaces & 268 & 1 & 5 & 3.80 & 0.934 \\
\hline Green spaces & 268 & 1 & 5 & 3.98 & 0.819 \\
\hline Availability of retail shops & 269 & 1 & 5 & 3.88 & 0.841 \\
\hline Educational facilities & 269 & 1 & 5 & 4.15 & 0.787 \\
\hline The quality of the air & 269 & 1 & 5 & $c>3.59$ & 0.849 \\
\hline The noise level & 269 & 1 & 5 & $\Rightarrow 3.34$ & 0.958 \\
\hline Cleanliness & 269 & 1 & 5 & 3.89 & 0.857 \\
\hline Safety & 269 & 1 & 5 & $>3.59$ & 0.896 \\
\hline Job opportunities & 269 & 1 & 5 & 3.11 & 0.878 \\
\hline
\end{tabular}

Finally, a stepwise multiple regression analysis was conducted to determine which city attributes had the greatest relative impact on students' overall satisfaction with life in Jelgava. The results revealed that five city attributes explained $38.8 \%$ of students' overall satisfaction with life in the city of Jelgava and they statistically significantly predicted overall satisfaction (Adjusted $R^{2}=0.388$, $F=32.481, p<0.000)$. As it is shown in Table 2, these attributes were the sense of belonging, satisfaction with the current housing, educational facilities, noise level and cultural facilities. Similar as in the empirical study in New Zealand [3] also in the case of Jelgava this set of attributes covers the students' perception of accommodation, social life, leisure as well as the city's atmosphere and environment. These attributes are the key drivers of students' overall satisfaction with life in Jelgava city, therefore, the university in collaboration with the city's administration should take this into 
account and have to pay special attention to these attributes in order to increase students' satisfaction with their study time.

Table 2

Multiple regression analysis for students' overall satisfaction with life in Jelgava

\begin{tabular}{|l|c|c|c|}
\hline $\begin{array}{l}\text { City attribute } \\
\text { (predictor variable) }\end{array}$ & $\boldsymbol{\beta}$ & $\begin{array}{c}\text { Accumulated } \\
\text { adjusted } \boldsymbol{R}^{\mathbf{2}}\end{array}$ & $\boldsymbol{p}$-value \\
\hline Sense of belonging & 0.240 & 0.209 & $p<0.0005$ \\
\hline Satisfaction with current housing & 0.275 & 0.286 & $p<0.0005$ \\
\hline Educational facilities & 0.196 & 0.344 & $p<0.0005$ \\
\hline Noise level & 0.171 & 0.373 & $p=0.001$ \\
\hline Cultural facilities & 0.145 & 0.388 & $p=0.007$ \\
\hline
\end{tabular}

\section{Conclusions}

1. Students' satisfaction with the hosting city is an important factor both for the university and the host city in order to provide pleasant study time. Satisfied students have better educational performance, they are more socially active and involve in university's as well as city's social, cultural and economical life. Satisfied students are the best advertisers for new students and can promote the increase in the number of future students. It is more likely that the university graduates, who are satisfied with their study time in the city, may consider staying in the city after graduation, thus increasing the share of highly educated people, which is one of the main drivers for sustainable development of any city.

2. Overall satisfaction with life in Jelgava among students who study at the Latvia University of Life Sciences and Technologies and currently live in the city is rather average, as $69.1 \%$ of respondents were satisfied with this indicator. Students' satisfaction level with Jelgava is lower compared with the permanent inhabitants of Jelgava. The results revealed that the gender, nationality and housing tenure did not influence students' satisfaction with overall life in the host city, while by contrast an occupation, age, type of housing, duration of residence and the previous residential place influence it.

3. The key drivers of students' overall satisfaction with life in Jelgava city are the sense of belonging, satisfaction with the current housing, educational facilities, noise level and cultural facilities.

4. In the case of Jelgava, $64 \%$ of students expressed satisfaction with their residence. The most satisfied were students who lived in private houses, while students from dormitories were the least satisfied with their housing conditions.

5. About a half of the respondents feel a rather high or very high sense of belonging to Jelgava and it is influenced by the students' age, housing tenure and duration in the current residence.

6. The highest level of satisfaction among students was with such attributes of Jelgava as educational facilities, green spaces, cleanliness and availability of retail shops, cultural facilities, public spaces and sports facilities, while moderate satisfaction was observed with the quality of the air, safety, the state of the streets and buildings and the noise level. At the same time, the lowest satisfaction was observed with public transport, job opportunities and healthcare services.

\section{Acknowledgement}

This study was supported by National Research Program Project No .VPP-IZM-2018/1-0015.

\section{References}

[1] El-Hilali N., Al-Jaber S., Hussein L. Students' Satisfaction and Achievement and Absorption Capacity in Higher Education. Procedia - Social and Behavioural Sciences, vol. 177, 2015, pp. 420-427.

[2] Gruber T., Fuss S., Voss R., Glaeser-Zikuda M. Examining student satisfaction with higher education services: using a new measurement tool. International Journal of Public Sector Management, vol. 23(2), 2010, pp. 105-123. 
[3] Insch A., Sun B. University students' needs and satisfaction with their host city. Journal of Place Management and Development, vol. 6, No.3, 2013, pp. 178-191.

[4] Fabula S., Boros L., Kovacs Z., Horvath D., Pal V. Studentification, diversity and social cohesion in post-socialist Budapest. Hungarian Geographical Bulletin, vol. 66 (2), 2017, pp. 157-173.

[5] Krabel S., Flöther C. Here Today, Gone Tomorrow? Regional Labour Mobility of German University Graduates, Regional Studies, vol.48:10, 2014, pp. 1609-1627.

[6] Cubillo J.M., Sanchez J., Cervino J. International students' decision-making process. International Journal of Educational Management, vol. 20(2), 2006, pp. 101-115.

[7] Studentu sociālie un ekonomiskie dzīves apstākḷi Latvijā (Social and economic conditions of student life in Latvia). EUROSTUDENT IV, SKDS, 2009 (In Latvian). [online] [15.03.2019]. Available at: https://www.izm.gov.lv/images/statistika/petijumi/15.pdf

[8] Studentu sociālie un ekonomiskie dzīves apstākḷi Latvijā (Social and economic conditions of student life in Latvia). Eurostudent VI, University of Latvia Philosophy and Sociology Institute, 2017 (In Latvian). [online] [01.03.2019]. Available at: http://www.lsa.lv/petijums-studentusocialie-un-ekonomiskie-apstakli-latvija/

[9] Licite L., Janmere L. Student expectations towards physical environment in higher education. Proceedings of International scientific conference "Engineering for rural development", May 2325, 2018, Jelgava, Latvia, vol. 17, 2018, pp. 1198-1203.

[10]Pārskats par Latvijas augstāko izglītību 2017.gadā (Review of Latvia's Higher Education in 2017). (In Latvian). Ministry of Education and Science. [online] [02.02.2019]. Available at: https://www.izm.gov.lv/images/statistika/augst_izgl/AII_2017_parskats.pdf

[11]Feldmane L. Life Quality Assessment in the City of Jelgava. Proceedings of the 2018 International Conference "Economic Science for Rural Development", No. 48, Jelgava, LLU ESAF, 2018, pp. 85-92.

[12] Lu M. Determinants of Residential Satisfaction: Ordered Logit vs Reggresion Models. Growth and Change, vol. 30, 1999, pp. 264-287.

[13] Nowok B., van Ham M., Findlay A.M., Gayle V. Does Migration Make You Happy? A Longitudinal Study of Internal Migration and Subjective Well-being. Environment and Planning, vol. 45, 2013, pp. 986-1002.

[14] Ballas D., Tranmer M. Happy People or Happy Places? A Multilevel Modeling Approach to the Analysis of Happiness and Well-Being. International Regional Science Review, vol. 35(I), 2012, pp. 70-102.

[15] Insch A., Florek M. Place Satisfaction of City Residents: Findings and Implications for City Branding. In G. Ashworth \& M. Kavaratzis (Eds.), Towards effective place brand management: Branding European Cities and Regions, 2010, pp. 191-204.

[16] Smith K.M. The relationship between residential satisfaction, sense of community, sense of belonging and sense of place in a Western Australian urban planned community. 2011. 353 p. [online] [02.02.2019]. Available at: https://ro.ecu.edu.au/theses/460 